\title{
Demographic expansion, despotism and the colonisation of East and South Polynesia
}

\author{
Douglas J. Kennett \\ Department of Anthropology, University of Oregon, USA \\ dkennett@uoregon.edu \\ Bruce Winterhalder \\ Department of Anthropology, University of California Davis, USA
}

\section{Introduction}

The Pacific Islands were some of the last habitable places on earth to be colonised by humans. Current archaeological evidence suggests these islands were colonised from c. 35,000 BP, and the expansion to increasingly remote islands and archipelagos was episodic rather than continuous; with bursts of migration followed by longer periods of sedentism and population growth (Anderson 2001a). The last phase of colonisation into East and South Polynesia occurred rapidly at c. $1000 \mathrm{BP}$, after a 1600-year hiatus in colonisation activity (Spriggs and Anderson 1993; Anderson 2001a, 2003).

We argued in an earlier paper (Kennett et al. 2006) that the episodic nature of oceanic colonisation is consistent with the predictions of Ideal Free Distribution (IFD), a population ecology model that considers the dynamic character of island suitability, along with densitydependent and density-independent variables influencing migratory behaviour. We also suggested intensive food production was one variable that contributed to decreasing suitability of island habitats, stimulating dispersal, and ultimately migrations to more distant islands in Oceania.

One of the primary assumptions of the IFD model is that all members of a group have equal competitive abilities and access to resources. Missing from our original model was an evaluation of changing despotic behavior. Despotic behaviour is an extreme bias in the control of resources by certain individuals (Summers 2005), which is documented in many Polynesian chiefdoms (Kirch 2000; Kirch and Kahn 2007). In this paper, we develop a model known as Ideal Despotic Distribution (IDD), and use it to evaluate the sociopolitical context for the colonisation of East and South Polynesia. 


\section{Ideal Free Distribution}

Ideal Free Distribution (IFD) was developed in population ecology (Sutherland 1996; McClure et al. 2006; Shennan 2007), and it provides a starting point for predicting when individuals will disperse or migrate to a new habitat, based on density-dependent changes in the suitability of the habitats available to them (Kennett et al. 2006). Habitats are ranked by their quality, as assessed by the fitness of the initial occupant. Typically, fitness-related measures are used to measure quality or suitability (e.g. production of young, rate of food intake; see Winterhalder and Kennett 2006).

Quality is density-dependent and declines due to competition as populations increase. Competitors may use up resources directly - for instance, by consuming and depleting food supplies; or they may indirectly make resources harder to find or capture - for instance, by stimulating their dispersal or elevated wariness, or they may render resources less desirable due to contamination or by fighting over them. The former is known as depletion competition, the latter as interference competition (Sutherland 1996:9).

The two primary assumptions of IFD are that: (1) individuals will elect to reside in the ideal or best habitat available to them; and (2) they are free or unrestricted to make this choice. They are also assumed to be competitors with equal ability and access to resources. Under these conditions, colonising individuals will settle first in the best habitat available. The suitability of these highranked habitats decreases as populations increase due to immigration or in situ growth. When the habitat is diminished to the quality level of the second-ranked habitat, further population growth stimulates immigration, with populations moving to a wider range of habitats. Because each individual is ready to relocate if another habitat offers an edge in suitability, the population distribution will equalise marginal qualities across all occupied habitats. This is an equilibrium distribution, and is a consequence of the marginal equalisation of habitat suitability. In IFD, no individual has an incentive to relocate.

\section{Despotism and Ideal Despotic Distribution}

The assumption in IFD that all individuals are competitors of equal ability in the quest for resources is unrealistic, particularly in Polynesia where highly ranked chiefdoms were well established historically (Kirch 1984; Kirch and Kahn 2007). Despotism - or extreme bias in the control of resources by select individuals - is common in highly ranked societies (Summers 2005). Status competition and social inequality exist in all human groups, regardless of size or mode of production (Fried 1967; Boehm 2000; Diehl 2000). However, archaeological evidence for significant and institutionalised intra-group differences in status and wealth is confined to the past 13,000 years, well after the first evidence for anatomically modern humans in Africa (c. 150,000 years ago) and their subsequent appearance throughout much of the Old and New Worlds (Klein 2004). The preponderance of archaeological evidence suggests that for the majority of human history, groups remained small, occupied relatively large territories at low densities, and moved periodically to adapt to spatial and temporal fluctuations in resources. The archaeological record also indicates that group fissioning, environmental infilling and emigration to diverse habitats were generally favoured over localised increases in group size and density, or other forms of intensification. Under these conditions, institutionalised hereditary leadership and significant differences in status and wealth rarely emerged or persisted.

Archaeological evidence for ranked societies is often found in conjunction with clear indications of localised population aggregation, economic intensification and territorial circumscription (Carneiro 1970; Hayden 1981; Clark and Blake 1994; Blake and Clark 
1999). In some instances, it co-occurs with a heightened commitment to agriculture (Price and Gebauer 1995), but similar developments also occurred among hunter-gatherers in areas where wild resources were concentrated, as with rich marine and aquatic habitats (Yesner 1980; Pálsson 1988; Erlandson 2001; Kennett 2005). In these locations, certain group members were able to acquire greater wealth and status by: (1) manipulating economic, social and political relationships to their own benefit (Earle 1987, 1997); (2) controlling the flow of exotic goods used to signal status (Flannery 1972); (3) monopolising the labour of other group members (Earle 1987; Arnold 2001); and (4) creating ideologies that justified the uneven distribution of wealth and power (Earle 1987, 1997). Increased control of resources, and, in some instances, differential reproduction (Betzig 1986) by a small number of high-status individuals accompanies the emergence of social ranking.

Ideal Despotic Distribution (IDD) is a variant of IFD that allows for individuals with different competitive abilities, highlighting competition and the possibility of differential access to resources within, and among, groups. If interference arises among competitors of unequal abilities, or if, by establishing territories, superior competitors or competing groups can protect themselves from density-dependent habitat deterioration by defending better resource opportunities, then the inferior competitors and those without territories are pushed to poorer habitats. Compared with IFD, a despotic distribution will reach equilibrium with disproportionate numbers or densities in the lower-ranked habitats. This makes intuitive sense: by garnering disproportionate resources in the best habitats, the better competitors push inferior ones more rapidly into habitats of lesser suitability. In many empirical studies, IFD serves as a null hypothesis, against which one can measure the effects of interference competition and unequal resource access (Sutherland 1996).

The decision by an individual or subgroup to leave or fission from its parent community depends on the risks of staying, the costs of moving, the likely success of relocating, and the relative advantages of alternative settlement locations. Relative advantage is dependent on the availability and suitability of adjacent habitats, and the behaviour of other groups in the area. Localised population increase, from endogenous growth or in-migration, followed by community fission, results in environmental infilling and the occupation of increasingly marginal zones (environmental packing; Binford 1968, 1983). Localised decreases in habitat suitability due to depletion or interference will stimulate group fission and emigration until most habitable areas are occupied. People may live in large groups, even under severely disadvantaged conditions, if they are circumscribed environmentally, demographically, or socially (Carneiro 1970). Circumscription includes social boundaries maintained by the threat of violence from adjacent communities, real or perceived. Socialisation for fear of others is a common form of coercion used to manipulate subordinate members of a group (Kantner 1999; Lekson 2002), and it can be used to reduce the attractiveness of settlement locations. In other words, subordination to members of one's own group may be the best alternative open to an individual. Ideological manipulation can also play an important role in the perception of the costs and benefits of staying with the group and being subjugated and exploited by others (Earle 1987).

\section{Colonisation of Polynesia}

The first appearance of people in Fiji and West Polynesia is signalled by the Lapita cultural complex, and is more broadly associated with the rapid spread of people from Island Southeast Asia (Bellwood 2001:Figure 1). Biological and linguistic data suggest the archaeological record of Lapita relates to an expansion of Austronesian-speaking people (Diamond and Bellwood 2003). Lapita-age settlements of 3300 to $2600 \mathrm{BP}$ are identified by the presence of distinctive dentate- 


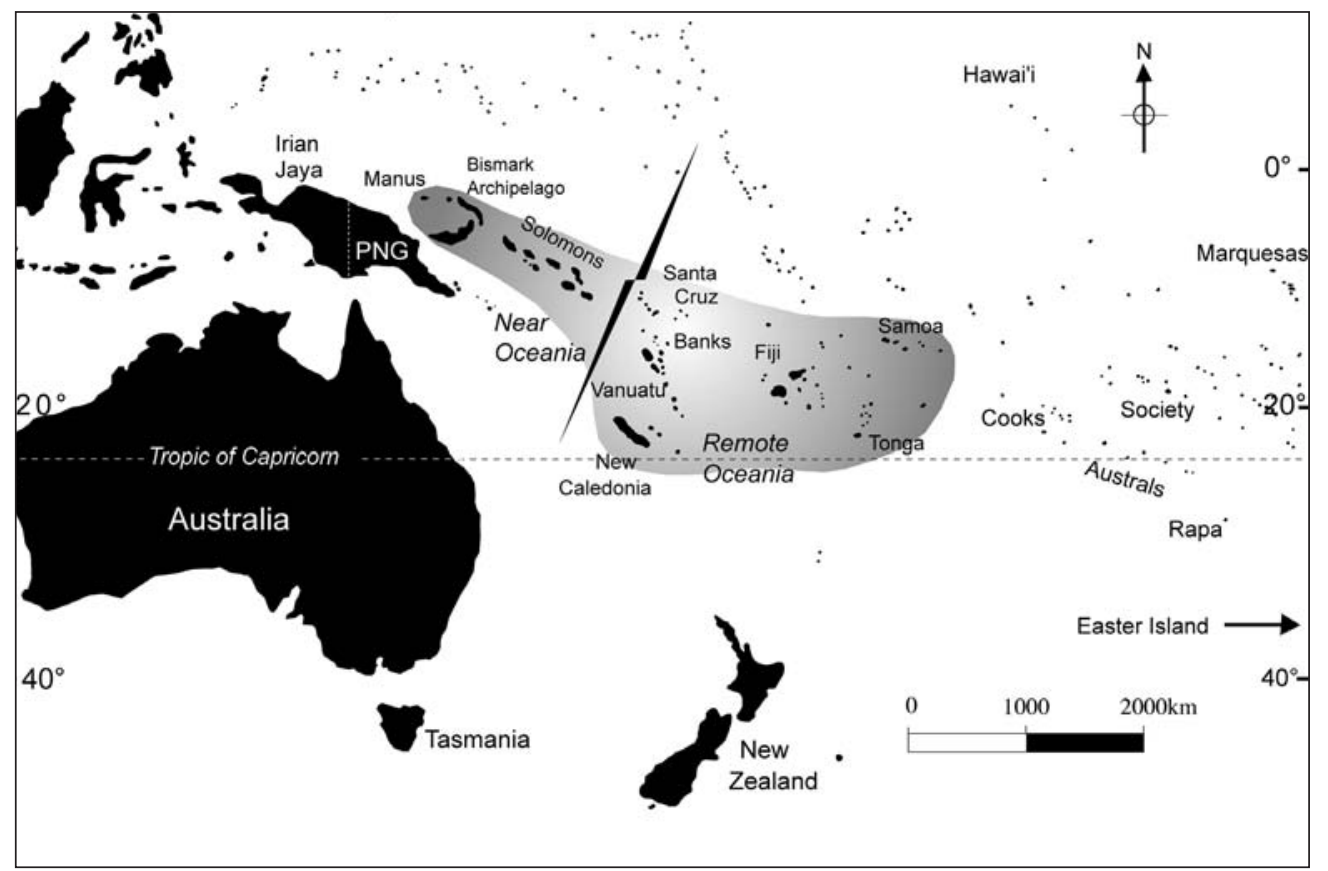

Figure 1. Map of 0ceania showing the relevant islands and archipelagos. Arrow demarcates near and remote Oceania.

stamped and incised pottery (Kirch 1997; Anderson et al. 2001). An inventory of locations containing dentate-stamped pottery includes about 184 locations, extending $4500 \mathrm{~km}$ from the Bismarck Archipelago, southeast to Fiji, Tonga, Samoa and Wallis (Uvea) in the South Pacific (Anderson et al. 2001). The appearance of Lapita pottery east of the Solomon Islands represents the earliest known colonisation of Remote Oceania (Kirch and Hunt 1988). Sites throughout the Lapita range are most common in coastal contexts, with overall densities on larger islands being lower than smaller islands (Anderson 2001a). The earliest Lapita settlements in Fiji date to between $3000 \mathrm{BP}$ and $2600 \mathrm{BP}$, with slightly later ages for the earliest Tongan and Samoan settlements, of 2950-2650 BP (Burley 1998; Anderson et al. 2001).

Recent archaeological studies suggest a hiatus of c. 1600 years between the expansion of Lapita peoples into Fiji and West Polynesia and the colonisation of more remote islands and archipelagos in East and South Polynesia (Anderson and Sinoto 2002; Anderson 2003). Spriggs and Anderson (1993) argued the initial colonisation of East Polynesia did not occur before 1600-1400 BP, but a series of more recent studies suggests it may have occurred closer to 1000 BP. In the Society Islands, archaeological deposits date no earlier than 1000 BP (Anderson et al. 1999), and current data from the Marquesas indicate settlement at 900 BP (Rolett and Conte 1995; Rolett 1998). On the remote fringes of East Polynesia, recent information suggests Easter Island (Rapa Nui) was colonised by 800 BP (Hunt and Lipo 2006), and certainly no earlier than 1000 BP (Steadman et al. 1994), Hawaii about 1000 BP (Athens et al. 1999), the Gambier Islands at 900 BP (Anderson et al. 2003), Rapa at 800 BP (Kennett et al. 2006), and New Zealand (Anderson 1991; Higham et al. 1999), along with several other South Polynesian islands, by 800 BP (Johnson 1995; Anderson and O'Regan 2000; Anderson and White 2001).

Colonisation of East Polynesia also includes the 25 'mystery islands' (e.g. Christmas, Norfolk and Pitcairn Islands) that were all colonised after 1000 BP, then abandoned before European contact (Anderson 2001b; Anderson et al. 2002). The revised archaeological ages for settlement are generally consistent with palaeoenvironmental records of anthropogenic vegetation change 
(Athens et al. 1999; McGlone and Wilmshurst 1999; Anderson 1995, 2002; Burney 2002). The conclusion is that the colonisation of East and South Polynesia was late and rapid.

\section{Sociopolitical context for the colonisation of East and South Polynesia}

Archaeological information suggests a long period of population infilling after Lapita settlements were established in the Fijian, Tongan and Samoan archipelagos. The post-Lapita cultural sequences are remarkably similar in Fiji/West Polynesia and suggest parallel processes and continuous cultural interactions (Kirch 2000). Settlement-pattern data for these island groups indicate: (1) an increased number of settlements in coastal locations and in previously unoccupied islands in an archipelago (Spennemann 1989; Burley 1998); (2) an increase in the size of settlements (Burley 1998:363) and a reduction in settlement mobility (Clark 1999); (3) the expansion of populations into the interiors of larger islands (Hunt 1987; Burley 1998; Clark 1999; Field 2004, 2005); (4) intensified agricultural practices, inferred from inland expansion and the development of terracing and irrigation systems (Burley 1998; Kirch 1994). Burning, deforestation and resource depression parallel the increased reliance on horticulture, and eventually intensive forms of agriculture develop (Burley 1998; Anderson 2002; Steadman et al. 2002). All these observations are consistent with the predictions of the IFD model (Kennett $e t$ al. 2006).

Increasing despotism in Fiji and West Polynesia may have also played a role, particularly for the rapid colonisation of East and South Polynesia. Hierarchically organised societies with despotic chiefs were present throughout Polynesia by the time of historic contact (Kirch 1984; Kirch and Kahn 2007). Chiefs controlled agricultural production via land ownership and by manipulating labour to increase subsistence yields. Individual households increased agricultural production by making permanent modifications to the land (e.g. terraces and canals) and/or increasing labour investment (e.g. weeding and mulching). Status rivalry between competing chiefs was strongly developed and wars were waged, in part, to seize the productive agricultural land of competitors.

Kirch (2000) has argued on linguistic grounds (e.g. words for corporate groups and positions of status) that the concept of hierarchical sociopolitical structure was present in the Ancestral

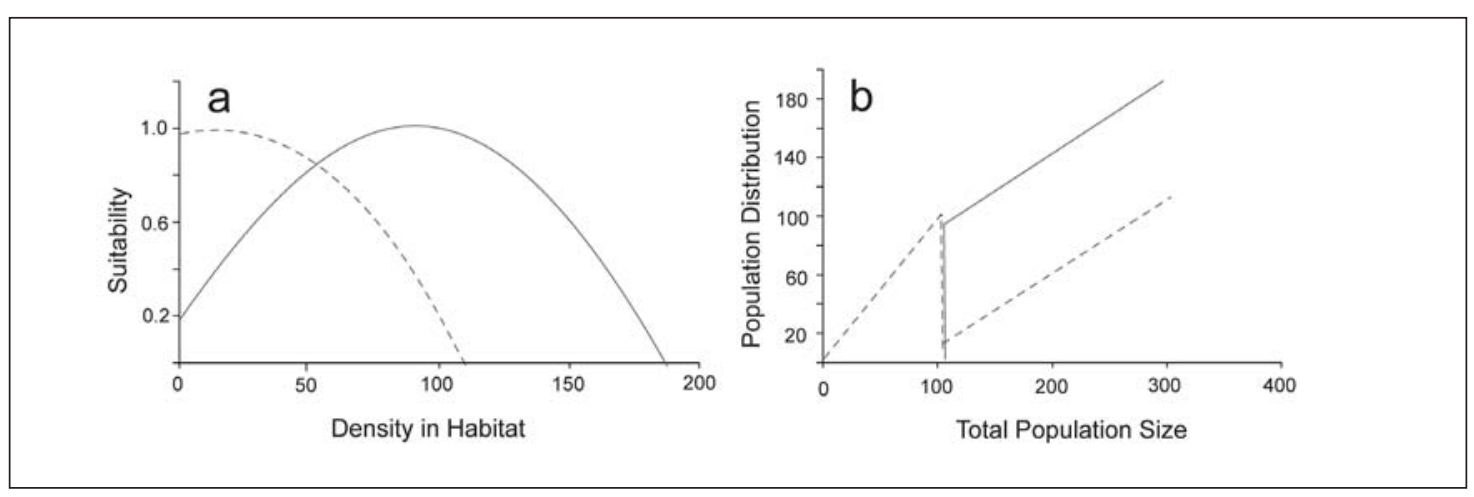

Figure 2. The Ideal Free Distribution (IFD) model determines the equilibrium distribution of populations over habitats (or spatially separable production opportunities), as a function of density and density-dependent suitability. The Ideal Despotic Distribution (IDD) model is similar, but allows for territoriality or other forms of resource defence. This example depicts the IFD and two habitats. (a) Suitability in the highest-ranked habitat declines monotonically with population growth; suitability in the second-ranked habitat first increases due to economies of scale (Allee effect), and then declines. (b) Individuals populate the highest-ranked habitat until its marginal suitability drops to the level for entry into the second-ranked habitat. There is then a rapid migration from the first to the second habitat, depopulating one and filling the other, until their marginal suitabilities again equalise and further growth is divided between them. 
Polynesia groups that colonised and developed in Fiji and West Polynesia during the Lapita era. The degree of sociopolitical stratification in Polynesian societies is strongly correlated with population size and density (Kirch 1984:98-99). Population density in Fiji and West Polynesia clearly increased between initial Lapita settlement (c. 3000 BP) and the next major wave of colonisation into East Polynesia at 1000 BP. Plainware ceramics (2650-1550 BP) are spread across agricultural fields throughout the Tongan archipelago (Burley 1998:363), and occur in coastal and interior settlements (Spennemann 1989). Interior portions of the Sigatoka Valley on the island of Viti Levu (Fiji) were colonised for the first time by c. 2000 BP (Field 2005), a general trend visible in both Fiji and Samoa (Marshall et al. 2000). Site size and complexity also increased in comparison with the small coastal settlements common in the Lapita era (Burley 1998; Field 2004). Within this context, competition for land would have been an important factor in the emergence of social hierarchies, but direct archaeological evidence for these hierarchies is meager until about $1000 \mathrm{BP}$.

The appearance of more intensive forms of agriculture before 1000 BP is suggestive of emerging social hierarchies. Pond field irrigation systems were being built to grow Colocasia on the island of Futuna by c. 1300 BP (Kirch 1994). Walled dry-field agricultural systems were also expanding at this time on Futuna and the adjacent island of Alofi, and similar trends are visible in Tongan islands and in Fiji (Field 2004). Intensive agricultural systems are generally absent in Samoa, even in late prehistory when centralised polities are known to have existed. The appearance of innovative and intensive large-scale agricultural systems is partly related to the expansion of populations. However, Kirch (2000) points out that these systems were often constructed and maintained to generate agricultural surplus for despotic chiefs.

Corporate group formation and status rivalry is suggested by the increase in inter-group conflict in Fiji and West Polynesia between 1500 and 1000 BP. The fortified hilltop settlement of Tatanga-matau on the island of Tutuila (Samoa) was in use as early as $1000 \mathrm{BP}$, with most activity dating to between c. 700 and 600 BP (Leach and Witter 1990). Hilltop settlements on Futuna and Alofi are synchronous with the appearance of pond and walled field agricultural systems at 1300 BP (Kirch 2000:227). Defensive locations were employed in parts of Fiji between 1500 and 1000 BP (Field 2004, 2005), with the first large hilltop fortifications appearing at c. 1000 BP (Best 1984), and a range of other defensive sites in use by historic contact (e.g. ring ditch forts, refuges; Parry 1977, 1982, 1987). In the Sigatoka Valley of Viti Levu, many fortifications were positioned in close proximity to agricultural fields, and appear to have been strategically placed to defend these lands (Field 2005:598). The appearance of fortifications in Fiji and West Polynesia generally correlates with land improvements that would have increased their value and economic defensibility (Dyson-Hudson and Smith 1979). Warfare and territorial conquest were despotic strategies for increasing surplus production and the asymmetric distribution of wealth.

Monumental architecture is highly visible and is closely connected with political power and social hierarchies in Polynesia (Graves and Green 1993; Kirch 2000). Large-scale structures include earth and stone mounds used as platforms for high-status residences or for chiefly burials. The Pulemelei mound of Savai'i island on Samoa is a massive stepped platform that possibly served as a residence for the high chief Lilomaiave Nailevaiiliili in the 17th century (Kirch 2000; Clark and Martinsson-Wallin 2007). Monumental architecture first appears in Tonga and Samoa between about 1000 and 800 BP (Burley 1998; Green 2002), a date consistent with genealogical records for the origins of the Tongan chiefdom at 1000 BP (Gifford 1929). Clark and Martinsson-Wallin (2007) point out that the appearance of monumental architecture, and the stratified social structure that it represents, is coincident with the major colonisation pulse 
into East Polynesia. These data point to West Polynesia as the ultimate conceptual source of hierarchical social structures, and this provides an important socio-political mechanism for rapid population dispersal into East and South Polynesia.

\section{Conclusions}

The evidence for colonisation of East and South Polynesia starting c. 1000 BP, if accurate, suggests these migrations were initiated from West Polynesia in the context of: (1) increasing population density; (2) decreasing habitat suitability due to erosion and soil degradation, after an initial increase in habitat suitability for agriculture due to forest clearance and terracing; (3) heightened interference due to territoriality and warfare. These observations are all consistent with the IFD model as originally constructed (Kennett et al. 2006). However, the rapid movement of people into East and South Polynesia after c. 1000 BP is more consistent with the IDD. Agricultural intensification, warfare, the construction of large monumental structures and substantial landscape modification from c. $1500 \mathrm{BP}$ to $1000 \mathrm{BP}$ suggests that hierarchical subjugation and despotic control of land initially stimulated population dispersal. The replication of this sociopolitical system was a key mechanism for 'pushing' migrants to the remote fringes of East and South Polynesia.

\section{Acknowledgements}

This paper was written with fellowship support from the AHRC Centre for the Evolution of Cultural Diversity, Institute of Archaeology, University College London (DJK).

\section{References}

Anderson, A.J. 1991. The chronology of colonization in New Zealand. Antiquity 65:767-795.

Anderson, A.J. 1995. Current approaches in East Polynesian colonization research. Journal of the Polynesian Society 104:110-132.

Anderson, A. J. 2001a. Mobility models of Lapita migration. In G.R. Clark, A.J. Anderson and T. Vunidilo (eds), The Archaeology of Lapita Dispersal in Oceania: Papers from the Fourth Lapita Conference, June 2000, Canberra, pp. 15-23. Terra Australis 17.

Anderson, A. J. 2001b. No meat on that beautiful shore: the prehistoric abandonment of subtropical Polynesian islands. International Journal of Osteoarchaeology 11:14-23.

Anderson, A. J. 2002. Faunal collapse, landscape change and settlement history in Remote Oceania. World Archaeology 33:375-390.

Anderson, A. J. 2003. Entering uncharted waters: models of initial colonization in Polynesia. In M. Rockman and J. Steele (eds), Colonization of Unfamiliar Landscapes, pp. 169-189. London: Routledge.

Anderson, A.J. and G. O’Regan 2000. To the final shore: Prehistoric colonisation of the Subantarctic islands in South Polynesia. In A.J. Anderson and T. Murray (eds), Australian Archaeologist: Collected Papers in Honour of Jim Allen, pp. 440-454. Canberra: Coombs Academic Publishing. Anderson, A.J. and Y.H. Sinoto 2002. New radiocarbon ages of colonization sites in East Polynesia. Asian Perspectives 41:242-257.

Anderson, A.J. and J.P. White (eds) 2001. The Prehistoric Archaeology of Norfolk Island, Southwest Pacific. Records of the Australian Museum, Supplement 27.

Anderson, A.J., E. Conte, G. Clark, Y. Sinoto and F.J. Petchey 1999. Renewed excavations at the 
Motu Paeao site, Maupiti Island, French Polynesia: preliminary results. New Zealand Journal of Archaeology 21:47-66.

Anderson, A.J., S. Bedford, G.R. Clark, I. Lilley, C. Sand, G. Summerhayes and R. Torrence 2001. An inventory of Lapita sites containing dentate-stamped pottery. In G.R. Clark, A.J. Anderson and T. Vunidilo (eds), The Archaeology of Lapita Dispersal in Oceania: Papers from the Fourth Lapita Conference, June 2000, Canberra, pp. 1-13. Terra Australis 17.

Anderson, A.J., H. Martinsson-Wallin and P. Wallin 2002. The prehistory of Kiritimati (Christmas) Island, Republic of Kiribati. The Kon-Tiki Museum, Occasional Papers 6.

Anderson, A.J., E. Conte, P.V. Kirch, and M. Weisler 2003. Cultural chronology in Mangareva (Gambier Islands), French Polynesia: evidence from recent radiocarbon dating. Journal of the Polynesian Society 112:119-140.

Arnold, J.E. (ed) 2001. The Origins of a Pacific Coast Chiefdom: The Chumash of the Channel Islands. Salt Lake City: University of Utah Press.

Athens, J.S.; J.V. Ward, H.D. Tuggle and D.J. Welch 1999. Environment, vegetation change and early human settlement on the 'Ewa plain: a cultural resource inventory of Naval Air Station, Barber's Point, O'ahu, Hawaì. Part III: Paleoenvironmental investigations. Honolulu: International Archaeological Research Institute Inc.

Best, S. 1984. Lakeba: the prehistory of a Fijian Island. Unpublished PhD thesis, Department of Anthropology, University of Auckland.

Best, S. 2002. Lapita: A View from the East. New Zealand Archaeological Association Monograph No. 24.

Betzig, L. 1986. Despotism and differential reproduction. New York: Aldine.

Bellwood, P.S. 1984. The Great Pacific Migration. In Yearbook of Science and the Future for 1984, pp. 80-93. Chicago: Encyclopedia Britannica.

Bellwood, P. 2001. Early agriculturalist population diasporas? Farming, languages, and genes. Annual Review of Anthropology 30:181-207.

Binford, L.R. 1968. Post-Pleistocene adaptations. In S.R. Binford and L.R. Binford (eds), New Perspectives in Archaeology, pp.313-341. Chicago: Aldine Publishing Co.

Binford, L.R. 1983. In Pursuit of the Past: Decoding the Archaeological Record. New York: Thames and Hudson.

Blake, M. and J.E. Clark 1999. The emergence of hereditary inequality: the case of Pacific coastal Chiapas, Mexico. In M. Blake (ed), Pacific Latin America in Prehistory, pp. 55-73. Pullman: Washington State University Press

Boehm, C. 2000. Forager Hierarchies, innate dispositions, and the behavioral reconstruction of prehistory. In M.W. Diehl (ed), Hierarchies in Action: Cui Bono?, pp. 31-58. Carbondale: Southern Illinois University.

Burley, D.V. 1998. Tongan Archaeology and the Tongan Past, 2850-150 BP. Journal of World Prehistory 12:337-392.

Burney, D.A. 2002. Late Quaternary chronology and stratigraphy of twelve sites on Kaua'i. Radiocarbon 44:13-44.

Carneiro, R.L. 1970. A theory of the origin of the state. Science 169:733-738.

Clark, G.R. 1999. Post-Lapita Fiji: Cultural Transformation in the Mid-Sequence. Unpublished PhD thesis, Department of Archaeology and Natural History, Research School of Pacific and Asian Studies, Australian National University.

Clark, G. and H. Martinsson-Wallin 2007. Monumental architecture in West Polynesia: Origins, chiefs, and archaeological approaches. Archaeology in Oceania 42:28-40.

Clark, J.E. and M. Blake 1994. Power of prestige: competitive generosity and the emergence of rank in lowland Mesoamerica. In E.M. Brumfiel and J.W. Fox (ed), Factional Competition and Political Development in the New World, pp.17-30. Cambridge: Cambridge University Press.

Diamond, J. and P. Bellwood 2003. Farmers and their languages: the first expansions. Science 300:597-603. 
Diehl, M.W. 2000. Some thoughts on the study of hierarchies. In M.W. Diehl (ed), Hierarchies in Action: Cui Bono?, pp. 11-30. Carbondale: Southern Illinois University.

Dyson-Hudson, R. and E.A. Smith. 1978. Human territoriality: an ecological reassessment. American Anthropologist 80:21-41.

Earle, T. 1987. Chiefdoms in archaeological and ethnohistorical context. Annual Review of Anthropology 16:279-308.

Earle, T. 1997. How chiefs come to power: The political economy in prehistory. Stanford: Stanford University Press.

Erlandson, J.M. 2001. The Archaeology of aquatic adaptations: Paradigms for a new millennium. Journal of Archaeological Research 9:287-350.

Field, J.S. 2004. Environmental and climatic considerations: a hypothesis for conflict and the emergence of social complexity in Fijian prehistory. Journal of Anthropological Archaeology 23:79-99.

Field, J.S. 2005. Land tenure, competition and ecology in Fijian prehistory. Antiquity 79:586-600.

Flannery, K.V. 1972. The cultural evolution of civilizations. Annual Review of Ecology and Systematics $3: 399-426$.

Fried, M.H. 1967. The evolution of political society: An essay in political anthropology. New York: Random House.

Gifford, E.W. 1929. Tongan society. Bernice P. Bishop Museum Bulletin 61.

Graves, M.W. and R.C. Green (eds) 1993. The evolution and organisation of prehistoric society in Polynesia. New Zealand Monograph Association 19.

Green, R.C. 2002. A retrospective view of settlement pattern studies in Samoa. In T.N. Ladefoged and M.W. Graves (eds.), Pacific landscapes. Archaeological approaches, pp. 125-152. Los Osos: Easter Island Foundation:

Hayden, B. 1981. Research and development in the Stone Age: Technological transitions among hunter-gatherers. Current Anthropology 22:519-548.

Higham, T.G.F., A.J. Anderson, C. Jacomb 1999. Dating the first New Zealanders: The chronology of Wairau Bar. Antiquity 73:420-427.

Hunt, T.L. 1987. Patterns of human interaction and evolutionary divergence in the Fiji Islands. Journal of the Polynesian Society 96:299-334.

Hunt, T.L. and C.P. Lipo 2006. Late Colonization of Easter Island. Science DOI: 10.1126/ science. 1121879

Johnson, L. 1995. In the midst of a prodigious ocean: Archaeological investigations of Polynesian settlement of the Kermadec Islands. Auckland: Department of Conservation, Resource Series 11.

Kantner, J. 1999. Survival cannibalism or sociopolitical intimidation? Explaining perimortem mutilation in the American Southwest. Human Nature: An interdisciplinary biosocial perspective 10(1):1-50.

Kennett, D. J. 2005. The Island Chumash: Behavioral ecology of a maritime society. Berkeley: University of California Press.

Kennett, D.J., A. Anderson, M. Prebble, E. Conte and J. Southon, 2006. Human Impacts on Rapa, French Polynesia. Antiquity 80:340-354.

Kennett, D.J., A. Anderson, and B. Winterhalder 2006. The Ideal free distribution, food production, and the colonization of Oceania. In D.J. Kennett and B. Winterhalder (eds), Behavioral Ecology and the Transition to Agriculture, pp. 265-288. Berkeley: University of California Press.

Kirch, P.V. 1984. The evolution of the Polynesian chiefdoms. Cambridge: Cambridge University Press.

Kirch, P.V. 1994. The Wet and the Dry: Irrigation and agricultural intensification in Polynesia. Chicago: University of Chicago Press.

Kirch, P.V. 1997. The Lapita peoples: Ancestors of the Oceanic world. Oxford: Blackwell.

Kirch, P.V. 2000. On the road of the winds. An archaeological history of the Pacific Islands before European contact. California: University of California Press.

Kirch, P.V. and T.L. Hunt (eds) 1988. Archaeology of the Lapita Cultural Complex: A critical review. 
Thomas Burke Memorial Washington State Museum Research Report No. 5. Seattle: Burke Museum.

Kirch, P. V. and J.G. Kahn 2007. Advances in Polynesian Prehistory: A review and assessment of the past decade (1993-2004). Journal of Archaeological Research 15:191-238.

Klein, R.G. 2004. The human career: Human biological and cultural origins. Chicago: University of Chicago Press.

Leach, H.M. and D.C. Witter 1987. Tataga-Matau 'rediscovered'. New Zealand Journal of Archaeology 9:33-54.

Lekson, S.H. 2002. War in the Southwest, War in the World. American Antiquity 67:607-624.

Marshall, Y., A. Crosby, S. Matararaba and S. Wood. 2000. Sigatoka. The shifting sands of Fijian prehistory. University of Southampton Department of Archaeology Monograph No.1.

McClure, S.B., M.A. Jochim and C.M. Barton 2006. Human behavioral ecology, domestic animals, and land use during the transition to agriculture in Valencia, eastern Spain. In D.J. Kennett and B. Winterhalder (eds), Behavioral Ecology and the Transition to Agriculture, pp. 197-216. Berkeley: University of California Press.

McGlone, M.S. and J.M. Wilmshurst 1999. Dating initial Maori environmental impact in New Zealand. Quaternary International 59:5-16.

Pálsson, G. 1988. Hunters and gatherers of the sea. In T. Ingold, D. Riches and J. Woodburn (eds), Hunters and Gatherers 1: History, Evolution and Social Change, pp. 189-204. New York: Berg.

Parry, J. 1977. Ring-ditch fortifications: Ring-ditch fortifications in the Rewa Delta, Fiji: Air photo interpretation and analysis. Bulletin of the Fiji Museum No. 3.

Parry, J. 1982. Ring-ditch fortifications II: Ring-ditch fortifications in the Navua Delta, Fiji: Air photo interpretation and analysis. Bulletin of the Fiji Museum No. 7.

Parry, J. 1987. The Sigatoka Valley-Pathways into prehistory. Fiji Museum Bulletin No. 9.

Price, T.D. and A.B. Gebauer (eds) 1995. Last hunters-first foragers: New perspectives on the prehistoric transition to agriculture. Santa Fe: School of American Research Press.

Rolett, B.V. 1998. Hanamiai: prehistoric colonization and cultural change in the Marquesas Islands (East Polynesia). Yale University Publications in Anthropology 81.

Rolett, B.V. and E. Conte 1995. Renewed investigation of the Ha'atuatua Dune (Nuku Hiva, Marquesas Islands): A key site in Polynesian prehistory. Journal of the Polynesian Society 104:195-228.

Shennan, S. 2007. The spread of farming into Central Europe and its consequences: Evolutionary models. In T. Kohler and S.E. van der Leeuw (eds), Model-based Archaeology, pp. 143-157. Sante Fe: SAR Press.

Spennemann, D.H.R. 1989. 'Ata 'a Tonga mo 'Ata 'o Tonga: Early and later Prehistory of the Tongan Islands. Unpublished PhD thesis, Australia National University.

Spriggs, M. and A.J. Anderson. 1993. Late colonization of East Polynesia. Antiquity 67:200-217.

Steadman, D., P. Vargas and C. Cristino 1994. Stratigraphy, chronology and cultural context of an early faunal assemblage from Easter Island. Asian Perspectives 33:79-96.

Steadman, D.W., A. Plourde and D.V. Burley 2002. Prehistoric butchery and consumption of birds in the Kingdom of Tonga. Journal of Archaeological Science 29:571-584.

Summers, K. 2005. The evolutionary ecology of despotism. Evolution and Human Behavior 26:106-135.

Sutherland, W.J. 1996. From individual behaviour to population ecology. Oxford: Oxford University Press.

Winterhalder, B. and D. J. Kennett 2006. Behavioral ecology and the transition from hunting and gathering to agriculture. In D.J. Kennett and B. Winterhalder (eds), Behavioral Ecology and the transition to agriculture, pp.1-21. Berkeley: University of California Press.

Yesner, D.R. 1980. Maritime hunter-gatherers: ecology and prehistory. Current Anthropology 21:727-750. 